\title{
National attitudes concerning gun carrying in the United States
}

\author{
D Hemenway, D Azrael, M Miller
}

\begin{abstract}
Objectives-To determine public attitudes in the United States concerning gun carrying.

Setting-In the past 15 years, many state legislatures have passed laws making it easier for United States citizens to carry concealed firearms, not only on the street but into various locations, including churches and government buildings. Methods-National random digit dial telephone surveys conducted in 1996 and 1999 asked questions concerning the public's feelings of safety as more people in their community carry firearms, and whether, in the language of the question, respondents believe "regular" citizens should be allowed to carry guns into public or government buildings.

Results-Americans feel less safe rather than more safe as more people in their community begin to carry guns. By margins of at least nine to one, Americans do not believe that "regular" citizens should be allowed to bring their guns into restaurants, college campuses, sports stadiums, bars, hospitals, or government buildings. Conclusions-The public believes that increased gun carrying by others reduces rather than increases their safety. Overwhelmingly, the public believes that in many venues gun carrying should be prohibited.
\end{abstract}

(Injury Prevention 2001;7:282-285)

Keywords: firearms; gun carrying; attitudes; surveys

The United States has the highest rates of gun ownership in the developed world, ${ }^{1}$ and also the highest rates of gun homicide. Most homicide victims are killed by firearms. ${ }^{2}$

In response to the threat of violence, many Americans carry firearms for protection. In one national survey, $7.5 \%$ of the adult population reported carrying a gun for protection at least once in the past 12 months, one third of whom carried the gun on their person. ${ }^{3}$ Adolescents, adults, and criminals all report that a primary reason for carrying firearms is self protection. ${ }^{4-7}$

In recent years, many states have been mak-

Harvard School of Public Health, 677 Huntington Avenue, Boston, MA 02115, USA

D Hemenway

D Azrael

M Miller

Correspondence to:

Dr Hemenway

hemenway@hsph.harvard.edu ing it easier for residents to legally carry a concealed firearm. Between 1985 and 1996, 28 states significantly eased restrictions on concealed gun carrying. As of 2000, seven states effectively prohibit concealed gun carrying, 12 "may issue" states allow police to use discretion in granting permits to carry a concealed firearm, 30 "shall issue" states require licensing authorities to issue a permit to carry a concealed firearm to any applicant who meets minimum criteria for carrying (for example, is over 21 years old, has not been convicted of a felony), and one (Vermont) does not require a permit to carry a concealed firearm.

The "shall issue" gun carrying laws are usually quite permissive. For example, in 2000, 22 states allowed gun owners to carry concealed weapons even into places of worship. ${ }^{8}$ However, each church typically has the power to post signs limiting carrying within its boundaries.

Various studies have attempted to determine the effects of gun carrying laws on crime and violence, but with conflicting results. ${ }^{9-13}$ This report does not examine the actual effect of gun carrying laws on crime and violence, but instead focuses on public attitudes about gun carrying, using data from two national surveys.

\section{Methods}

Data come from two national random digit dial surveys conducted by Fact Finders, Inc of Del Mar, New York for the Harvard Injury Control Research Center in the spring of 1996 and the spring of 1999. The samples comprise, respectively, 1905 and 2521 adults living in the 50 US states.

Samples were stratified by state (proportional to population size according to the 1990 census). All households with a single telephone line, including those with unlisted numbers, had an equal probability of inclusion. Households without a telephone were excluded.

The surveys were designed to be representative of households and only one adult from each household was interviewed. Rather than interview whichever adult who happened to be home at the time of the call, interviewers alternately asked to speak with a man or with a woman living in the household. If there was no adult of the requested gender, the initial respondent was interviewed.

Once a telephone number was randomly selected, as many as 10 repeat phone calls were made until a final disposition was reached. In $1996,27 \%$ of contacted households refused to participate; in $1999,35 \%$ refused. Both surveys had a greater than $98 \%$ completion rate, comparable to other recent national firearm surveys. ${ }^{14} 15$

The key question in the 1996 survey asked: "Some states have recently changed their laws concerning gun carrying. If more people in your community begin to carry guns, will that make you feel more safe, the same, or less safe?"

The key questions on the 1999 survey asked, "Do you think regular citizens should be allowed to bring their guns into (a) restaurants, (b) college campuses, (c) sports stadium, (d) 
Table 1 "If more people in your community begin to carry guns, would that make you feel more safe, less safe or the same? (1 = more safe or same)

\begin{tabular}{|c|c|c|c|c|c|c|}
\hline & No & $\begin{array}{l}\% \text { Feel } \\
\text { more safe }\end{array}$ & $\begin{array}{l}\% \text { Feel } \\
\text { same }\end{array}$ & $\begin{array}{l}\% \text { Feel } \\
\text { less safe }\end{array}$ & $\begin{array}{l}\text { Adjusted } \\
\text { odds ratio }\end{array}$ & $\begin{array}{l}\text { Multivariate analysis } \\
95 \% \text { confidence } \\
\text { interval }\end{array}$ \\
\hline All & 1905 & 12 & 24 & 59 & & \\
\hline \multicolumn{7}{|l|}{ Gender } \\
\hline Male & 759 & $19^{\star \star \star}$ & 29 & 52 & 1.5 & 1.2 to $2.0(\mathrm{p}<0.001)$ \\
\hline Female & 1030 & 7 & 23 & 70 & & \\
\hline \multicolumn{7}{|l|}{ Race } \\
\hline White & 1446 & $13^{\star \star \star}$ & 27 & 60 & 1.5 & 1.1 to $2.1(\mathrm{p}<0.001)$ \\
\hline Other & 318 & 10 & 18 & 72 & & \\
\hline \multicolumn{7}{|l|}{ Age } \\
\hline$>40$ & 1021 & $14^{\star}$ & 25 & 61 & 0.9 & 0.7 to $1.2(\mathrm{NS})$ \\
\hline$<40$ & 757 & 11 & 26 & 63 & & \\
\hline \multicolumn{7}{|l|}{ Income $(\$)$} \\
\hline$>35000$ & 893 & 12 & 26 & 62 & & \\
\hline$<35000$ & 684 & 12 & 23 & 65 & 1.1 & 0.9 to $1.5(\mathrm{NS})$ \\
\hline Missing & 212 & 17 & 29 & 55 & 2.0 & 1.4 to $2.8(\mathrm{p}<0.001)$ \\
\hline \multicolumn{7}{|l|}{ Community } \\
\hline Urban & 627 & 11 & 20 & 70 & & \\
\hline Suburban & 592 & 12 & 24 & 64 & 1.3 & 1.0 to $1.7(\mathrm{NS})$ \\
\hline Rural & 547 & 15 & 33 & 53 & 1.7 & 1.3 to $2.2(\mathrm{p}<0.001)$ \\
\hline \multicolumn{7}{|l|}{ Children $<18$ years old } \\
\hline Yes & 760 & $10^{\star \star \star}$ & 25 & 65 & 0.8 & 0.6 to $1.0(\mathrm{p}<0.05)$ \\
\hline No & 1025 & 14 & 26 & 60 & & \\
\hline \multicolumn{7}{|l|}{ Gun owner } \\
\hline Yes & 439 & $30^{\star \star \star}$ & 38 & 33 & 4.2 & 3.2 to $5.6(\mathrm{p}<0.001)$ \\
\hline No, but gun in household & 290 & $6^{\star \star \star}$ & 32 & 63 & 1.7 & 1.2 to $2.3(\mathrm{p}<0.001)$ \\
\hline No gun in household & 1057 & 7 & 19 & 75 & & \\
\hline \multicolumn{7}{|l|}{ Carried gun } \\
\hline Yes & 54 & $44^{\star \star \star}$ & 35 & 20 & 2.5 & 1.2 to $5.1(\mathrm{p}<0.05)$ \\
\hline No & 1726 & 11 & 25 & 64 & & \\
\hline \multicolumn{7}{|l|}{ Region } \\
\hline South & 636 & $15^{\star}$ & 25 & 59 & 1.1 & 0.9 to $1.5(\mathrm{NS})$ \\
\hline Other & 1153 & 11 & 25 & 64 & & \\
\hline \multicolumn{7}{|l|}{ Neighborhood safety } \\
\hline Very/somewhat safe & 1502 & $12^{\star}$ & 26 & 62 & 0.9 & 0.6 to $1.2(\mathrm{NS})$ \\
\hline Somewhat/very unsafe & 253 & 17 & 19 & 64 & & \\
\hline \multicolumn{7}{|l|}{ Confidence in police } \\
\hline Feel confident & 1373 & $11^{\star \star \star}$ & 27 & 62 & 1.0 & 0.8 to $1.4(\mathrm{NS})$ \\
\hline Do not feel confident & 341 & 19 & 20 & 61 & & \\
\hline
\end{tabular}

${ }^{\star} \mathrm{p}<0.05 ;{ }^{\star \star} \mathrm{p}<0.01 ;{ }^{\star \star \star} \mathrm{p}<0.001$

Source: 1996 national random digit dial survey of 1905 adults by Fact Finders, Inc for the Harvard Injury Control Research Center.

bars, (e) hospitals, and (f) government buildings. To conserve interviewer time, the first 1500 respondents were asked only about the first three locations, and the remaining 1021 adults were asked only about the last three locations.

In both surveys, eight independent variables were examined: (1) gender; (2) race (white versus non-white); (3) age (aged 40 or over); (4) income (greater or less than $\$ 35000$ ); (5) community (city, rural, or suburban); (6) children (under 18) living at home; (7) gun in the household; (8) region (South or not). In addition, the 1996 survey included three additional variables: (1) gun carrying ("In the past 30 days have you carried a gun on your person?"); (2) safety of the area ("If you are out alone in your neighborhood at night, do you feel very safe, somewhat safe, somewhat unsafe, or very unsafe?"); and (3) confidence in police ("Are you confident or not confident that your local police will respond quickly if you call them about a crime?").

We used multiple logistic regression to analyze correlates of respondents' attitudes, holding other factors constant.

\section{Results}

In the 1996 survey, 59\% of respondents said they would feel less safe as more people in their community began to carry guns and $12 \%$ said they would feel more safe $(24 \%$ said they would feel the same and 5\% didn't know or
Table 2 National opinions about gun carrying in specific locations: "Do you think regular citizens should be allowed to bring their guns into..."

\begin{tabular}{llll}
\hline Location & $\%$ Yes & $\%$ No & $\%$ No opinion \\
\hline Restaurants & 10 & 88 & 2 \\
College campus & 4 & 94 & 2 \\
Sports stadium & 5 & 94 & 1 \\
Bars & 4 & 93 & 3 \\
Hospitals & 6 & 91 & 3 \\
Government buildings & 5 & 92 & 3 \\
\hline
\end{tabular}

Source: 1999 national random digit dial survey of 2521 adults conducted by Fact Finder, Inc for the Harvard Injury Control Research Center. Altogether 1500 adults were asked about the first three locations, and 1021 adults about the last three locations.

didn't respond) (table 1). The majority said they would feel less safe, independent of their age, race, gender, income, region, or whether they lived in a city, suburb, or rural area. The only subgroup for which a plurality would feel safer were those who had carried a gun on their person in the previous month.

In the bivariate and multivariate analyses presented in table 1, we eliminated more than 100 respondents because they were police officers, security guards, or because they did not respond to one or more of the questions dealing with the 11 independent variables. Of the remaining 1789 respondents, the groups significantly more likely than others to believe they would feel less safe were non-whites, urban dwellers, adults with children in the household, and people who do not own or carry guns.

In the 1999 survey, an overwhelming majority said "No," they did not think regular citizens should be allowed to bring their guns into restaurants (88\%), college campuses (94\%), sports stadiums (94\%), bars (93\%), hospitals (91\%), or government buildings $(92 \%)$. Ten per cent or fewer of respondents said "Yes" to any of the locations (table 2). For all independent variables a majority of respondents did not think regular citizens should be allowed to carry their firearms into any of the six specified locations (not shown). Women and non-gun owners were especially likely to believe that regular citizens should not carry guns into the six listed venues. For example, $96 \%$ of women, compared with $80 \%$ of men, and $95 \%$ of non-gun owners compared to $74 \%$ of gun owners, believed that guns should not be brought into restaurants (not shown).

\section{Discussion}

We find that most Americans believe they would feel less safe as more people in their community carry firearms. Our results are similar to other survey results that find that Americans are more likely to feel less safe rather than more safe if more people in their community acquire firearms. ${ }^{16}{ }^{17}$

Our results are also consistent with previous polls that find that the large majority of Americans are not favorably disposed to civilian gun carrying. For example, a 1991 CBS News/New York Times national telephone poll of 1430 adults asked "Do you think that when ordinary people carry weapons like guns or knives or mace they make the streets safer, or do you 
think carrying weapons creates more problems than it solves?" Sixty nine per cent answered "more problems," $15 \%$ said "safer", and 16\% said either "don't know" or did not answer.

Each year from 1996 to 1999 the National Opinion Research Center (NORC) asked a national sample of 1200 adults, "Do laws allowing any adult to carry a concealed gun in public provided that they pass a criminal background check and gun safety course make you feel more safe or less safe?" In 1996, the year of our survey, $56 \%$ replied less safe, compared with $36 \%$ who said more safe. Since then the percentages have gone up and down. The NORC surveys also asked "Most states require a special license to allow people to carry a concealed firearm. Should licenses to carry concealed firearms be issued to any adult who has passed a criminal background check and a gun safety course, or only to people with a special need to carry a concealed gun, such as private detectives?" Each year $54 \%-60 \%$ wanted to restrict the licenses to people with a special need to carry; about $40 \%$ preferred the other extreme-permissive "shall issue" laws, which require licensing authorities to issue permits to any applicant who meets specified criteria (for example, is not a convicted felon). ${ }^{18}$

An April 1999 NBC News/Wall Street Fournal poll of over 1000 adults nationwide asked "Do you approve or disapprove of the idea of passing new laws to make it easier for people to carry concealed weapons?" Seventy three per cent disapproved, while $22 \%$ approved.

Voting results appear consistent with the survey findings. In April 1999, Missouri held the first state referendum on gun carrying. (Missouri had initially banned the carrying of concealed weapons in 1875 when Jesse James was still at large.) Although the gun lobby spent some $\$ 3.8$ million on the campaign, an amount far greater than their opponents, the measure went down to defeat. Pre-election polling found that women were even more opposed than men to the permissive gun carrying proposal. ${ }^{19}$

Gun carrying is often opposed for specific sites. In the 1999 NORC survey, $76 \%$ of respondents believed that "public places, such as stores, movie theaters, and restaurants" should be allowed to prohibit people from bringing guns onto their premises. ${ }^{18}$ During the 1999 Missouri referendum, professional sports teams, fearing for the safety of players, fans, and referees, strongly opposed the relaxation of the gun carrying laws in their state. Union chiefs for baseball and football players were similarly opposed. Don Fehr, executive director of the baseball players association, wrote in a letter to baseball commissioner Bud Selig that the proposition was "one of the most dangerous ideas we have had to confront". ${ }^{20}$

Colleges often have strict regulations concerning guns. In 1994, the Association for Student Judicial Affairs unanimously adopted a resolution urging colleges to support tough rules to keep guns off campuses. ${ }^{21}$ The Mormon church, although based in Utah, where most households own guns, says that guns, even legally concealed firearms, do not belong in houses of worship. ${ }^{22}$

Permissive gun carrying laws have potential advantages. If carrying guns became more prevalent, more crimes might be thwarted and others not even attempted. On the other hand, permissive gun carrying laws may cause problems. Increased civilian gun carrying may cause some criminals to arm themselves, or to resort to violence more quickly when dealing with their victims. Moreover, increases in permitted gun carrying may make it more difficult for police to prevent illegal gun carrying. ${ }^{23}$ Guns can make arguments more lethal. People who are tired, angry, drunk, or afraid, and who are not trained in dispute resolution, may use guns inappropriately. Police officers, who receive large amounts of training, still are often inadequately prepared to handle ambiguous but potentially dangerous situations. Heavy stress, confusion, and fear are inherent in most possible shooting situations. Heart rates skyrocket, and it is difficult to think clearly and to act deliberately. Even police officers make serious mistakes. Not surprisingly, evidence indicates that much self described self defense gun use by regular citizens in America may be illegal and socially undesirable. ${ }^{1424-26}$

Our study focuses on people's beliefs and attitudes concerning gun carrying. A limitation of our study is that respondents were asked only a hypothetical question about their feelings of safety as more people begin to carry guns, and whether they believe "regular" citizens should be allowed to carry in six specific locations. We do not know why respondents said they would feel safer or less safe, nor why they do not believe "regular" Americans should be carrying guns into restaurants, bars, etc. Nor do we know how strongly respondents hold their opinions. As with all telephone surveys, ours is subject to sampling error (3\% for each question due to chance alone when $\mathrm{n}=1000$; under $2 \%$ when $\mathrm{n}=2500$ ), and to systematic error ${ }^{27}$ such as under-representing individuals who are institutionalized (for example, criminals) or without telephones (for example, people who are poor). ${ }^{28}$ Finally, self report data are subject to potential inaccuracies due to social desirability responses, intentional distortions, or noncandid responses. ${ }^{29}$ None the less, the size of the differences in our study suggest that eliminating all potential survey problems would not change our general results.

\section{Implications for prevention}

In the past 15 years, many state legislatures have made gun carrying laws more permissive, taking discretion as to who should be granted a gun carrying license away from the police. While people carry guns for safety reasons, our results indicate that most Americans believe that increased gun carrying by others makes them less safe rather than more safe and that concealed firearms should not be allowed into a large number of public venues. These 


\section{Key points}

- Over the past 15 years many state legislatures have made it easier for individuals to obtain permits to carry concealed firearms.

- In states that allow concealed carry there are few restrictions on where concealed firearms may be carried.

- Studies assessing the effect of laws making it easier to carry a concealed firearm have produced conflicting results.

- In terms of public opinion, Americans feel less safe rather than more safe as more people in their community begin to carry guns.

- By large margins, Americans do not believe that guns should be allowed in restaurants, bars, sports stadiums, hospitals or government buildings or on college campuses.

findings suggest that existing legislation regarding gun carrying may not adequately take into account the feelings and preferences of the large majority of United States adults and that, at least on these grounds, such legislation should be revisited.

1 Kleck G. Targeting guns: firearms and their control. New York: Aldine de Gruyter, 1997.

2 National Center for Health Statistics. US Department of Health and Human Services (http://www.cdc.gov/ncipc/ data).

3 Cook PJ, Ludwig J. Guns in America: results of a comprehensive national survey on firearms ownership and use. Washington, DC: Police Foundation, 1996

4 Hemenway D, Prothrow-Stith D, Bergstein JM, et al. Gun carrying among adolescents. Law and Contemporary Problems 1996;59:39-53.

5 Wright JD, Rossi PH. Armed and considered dangerous: a survey of felons and their firearms. Hawthorne, NY: Aldine de Gruyter, 1986.

6 Kleck G, Gertz M. Carrying guns for protection: results from the national self-defense survey. Fournal of Research on from the national self-defense survey. Fourne
Crime and Delinquency 1998;35:193-224.
7 Nelson DE, Grant-Worley JA, Powell K, et al. Population estimates of household firearm storage practices and estimates of household firearm storage practices
firearm carrying in Oregon. $\mathcal{F} A M A$ 1996;275:1744-8.

8 National Rifle Association-ILA Research and Informationstate laws (http://www.nraila.org) (summarized in Reuters, $4 / 14 / 00$. Senate Democrats push "safe havens" from guns).

9 McDowall D, Loftin C, Wiersema B. Easing concealed firearms laws: effects on homicides in three states. Fournal of Criminal Law and Criminology 1995;86:193-206.

10 Lott JR, Mustard DB. Crime, deterrence and right-to-carry concealed handguns. Fournal of Legal Studies 1997;26:1-68.

11 Black DA, Nagin DS. Do right-to-carry laws deter violent crime? Fournal of Legal Studies 1998;27:209-19.

12 Ludwig J. Concealed-gun-carrying laws and violent crime: evidence from state panel data. International Review of Law and Economics 1998;18:239-54.

13 Dezhbakhsh H, Rubin PH. Lives saved or lives lost? The effects of concealed-handgun laws on crime. American Economic Review 1998; 88:468-474.

14 Cook PJ, Ludwig J. Defensive gun uses: new evidence from a national survey. Fournal of Quantitative Criminology 1998; 14:111-31.

15 Kleck G, Gertz M. Armed resistance to crime: the prevalence and nature of self-defense with a gun. Fournal of Criminal Law and Criminology 1995;273:1749-54.

16 Hemenway D, Solnick SJ, Azrael DR. Firearms and community feelings of safety. Fournal of Criminal Law and Criminology 1995;86:121-32.

17 Miller M, Azrael D, Hemenway D. Community firearms, community fear. Epidemiology 2000;11:709-14.

18 Smith TW. 1998, 1999 National Gun Policy Survey of the National Opinion Research Center: research findings. University of Chicago: National Opinion Research Center, 1999; 2000 .

19 Edsall TB. Missouri voters defeat ballot measure to allow concealed handguns. Washington Post 7 April 1999.

20 Associated Press. Royals, Cardinals, Chiefs, Rams oppose Missouri gun bill. Jefferson City, Missouri, 25 March 1999.

21 Lederman D. Weapons on campus? Officials warn that colleges are not immune from the scourge of handguns. Chronicle of Higher Education 9 March 1994: A 33, 34.

22 Harrie D. LDS leaders toughen stand against guns. Salt Lake City Tribune 16 May 1999.

23 Ludwig J. Gun self-defense and deterrence. Crime and fustice: A Review of Research 2000;27:363-417.

24 Hemenway D, Azrael D. The relative frequency of offensive and defensive gun uses: results from a national survey. Violence and Victims 2000;15:257-72.

25 Hemenway D, Azrael D, Miller M. Gun use in the United States: results from two national surveys. Inj Prev 2000;6:263-7.

26 McDowall D, Loftin C, Presser S. Measuring civilian defensive firearm use: a methodological experiment. fournal of Quantitative Criminology 2000;16:1-19.

27 Frey J. Survey research by telephone. 2nd Ed. Newbury Park, CA: Sage Publications, 1989: 45-46.

28 Lavrakas P. Telephone survey methods. Beverly Hills, CA: Sage Publications, 1987: 13-15.

29 Aday L. Designing and conducting health surveys. San Francisco, CA: Jossey-Bass, 1989: 129-42.

\section{Youth poisoned by cooking product}

Alcohol based food essences, available to minors in unlicensed supermarkets, have been implicated in the death of a 15 year old Australian youth. A coronial hearing has been told that the youth collapsed after drinking imitation vodka essence, mixed with pineapple juice, at a party. It is estimated that he drank the equivalent of 22 standard alcoholic drinks in less than 30 minutes. These essences, in $375 \mathrm{ml}$ bottles, have an alcohol content of $70 \%$ and do not carry warnings. Three bottles were purchased by the mother of a boy who attended the party, at her son's request; she was latter convicted of supplying alcohol to minors and fined \$Aus100 (\$52 US). Since 1999 conditions for sale of alcohol based food essences have been set out under the Liquor Control Act. Under these controls food essences with alcohol content around $70 \%$ can only be sold in limited sizes; the size limits are $100 \mathrm{ml}$ for vanilla essence and $50 \mathrm{ml}$ for other essences. Above this size the products must be sold in licensed premises. (From The Age, 20 June 2001; Herald-Sun 19 June 2001. Contributed by Ian Scott)

\section{Conker tree hazards}

In June, Britain's Daily Telegraph newspaper (and subsequently many others) reported that 20 horse chestnut trees in Norwich were to be felled. Safety was at the heart of this heartless decision-children being hit by the sticks that they throw into the trees to release the conkers, or standing in the road to get better aim seemed to be the prime reasons. Slippery roads from squashed conkers and dented cars also got the blame. Now the city council have decided that sense will prevail and that the press had blown matters up out of all proportion. Only two trees will become firewood, after all. 